\title{
Understanding the build-up of a technological innovation system around hydrogen and fuel cell technologies
}

\author{
Roald A.A. Suurs ${ }^{a, b, *}$, Marko P. Hekkert ${ }^{a}$, Ruud E.H.M. Smits ${ }^{a}$ \\ a Innovation Studies Group, Copernicus Institute for Sustainable Development and Innovation, Utrecht University, Heidelberglaan 2, \\ 3584 CS Utrecht, The Netherlands \\ ${ }^{\mathrm{b}}$ TNO Built Environment and Geosciences, Business Unit Innovation and Environment, Van Mourik Broekmanweg 6, 2628 XE Delft, \\ The Netherlands
}

\section{A R T I C L E I N F O}

\section{Article history:}

Received 18 June 2009

Received in revised form

26 September 2009

Accepted 26 September 2009

Available online 31 October 2009

Keywords:

Fuel cell

Technological innovation system

System functions

Cumulative causation

\begin{abstract}
A B S T R A C T
This study provides insight into the development of hydrogen and fuel cell technologies in the Netherlands (1980-2007). This is done by applying a Technological Innovation System (TIS) approach. This approach takes the perspective that a technology is shaped by a surrounding network of actors, institutions and technologies. When a technology is in an early stage of development, a TIS has yet to be built up in order to propel technological progress. This build-up process is studied for the hydrogen and fuel cell innovation system in the Netherlands. This is done by systematically studying the dynamics of seven key activities that accelerated (or slowed down) developments around hydrogen and fuel cell technologies. The analysis contributes to a better understanding of these dynamics and of the drivers and barriers that caused them to emerge. The study derives important lessons for practitioners. (c) 2009 Professor T. Nejat Veziroglu. Published by Elsevier Ltd. All rights reserved.
\end{abstract}

\section{Introduction}

The fuel cell in combination with hydrogen is widely considered to play an important role in future sustainable energy systems [1-4]. According to this vision, hydrogen (based on renewables) is the energy currency of the future. As such it is to replace petrol, diesel, natural gas and electricity as dominant energy carriers. However, recurring technological, economic and societal barriers have held back the large scale diffusion of Hydrogen and Fuel cell (HyF) technologies.

The purpose of this study is to provide insight into the mechanisms that drive or hamper the development of HyF technologies over time. The basis for the analysis is the concept of the Technological Innovation System (TIS). A TIS is the network of actors, institutions (norms, regulations) and technologies that influences the development and diffusion of emerging technologies [5-7]. For HyF technologies such a system needs to be built up in order to make large scale diffusion possible. A TIS analysis provides insights into the dynamics of this build-up process. This is done by studying a set of seven key activities or 'system functions' [8]. Examples are knowledge development, entrepreneurial activities and market formation.

Central to this study is the notion of cumulative causation $[6,7,9,10]$. Cumulative causation is the phenomenon that the build-up of a TIS accelerates due to system functions interacting and reinforcing each other over time. For example, knowledge development is likely to benefit from entrepreneurial activities and entrepreneurial activities, in turn, will be induced by market formation. Various empirical studies have focused on the identification of forms of cumulative causation, also called motors of innovation, in the development of new energy technologies [7,11-14]. This literature

\footnotetext{
* Corresponding author. Currently at: TNO Built Environment and Geosciences, Business Unit Innovation and Environment, Van Mourik Broekmanweg 6, 2628 XE Delft, The Netherlands. Tel. +31 (0) 888662760.

E-mail address: roald.suurs@tno.nl (R.A.A. Suurs).

0360-3199/\$ - see front matter ๔ 2009 Professor T. Nejat Veziroglu. Published by Elsevier Ltd. All rights reserved. doi:10.1016/j.ijhydene.2009.09.092
} 
consistently shows how a rapid TIS build-up benefits from cumulative causation. This study adds to this literature by providing a detailed analysis of TIS dynamics underlying the historical development of HyF technology in the Netherlands.

The following research questions are central:

RQ1 : What motors of innovation constituted the development of the HyF Innovation System (HyFIS) in the Netherlands between 1980 and 2007?

RQ 2: What were the underlying drivers and barriers that explained the emergence of these motors of innovation in the HyFIS?

The Dutch HyFIS is an interesting research topic since it has developed for more than 50 years and Dutch government actors and industries have undertaken powerful attempts at commercialisation ever since the 1980s. ${ }^{1}$ Yet, HyF technologies are still in a pre-market development stage. It will be interesting to find out what types of dynamics have made this kind of development possible. Not least because such insights will be helpful for actors who intend to (further) accelerate the development and deployment of hydrogen and fuel cell technologies in the future, not only in the Netherlands but in other countries as well ${ }^{2}$.

The outline of this article is as follows: Section 2 provides an explanation of the theoretical concepts and indicates how these concepts were measured. In Section 3 a technological background is provided. Section 4 contains the results from the historical analysis and Section 5 concludes by answering the research questions.

\section{The technological innovation systems approach}

Technological innovation has long been considered the result of a linear development, starting with basic research, followed by applied R\&D, and ending with production and diffusion; see Godin [15] for a discussion of this topic. The different stages of the linear model of innovation were considered as separate, both in terms of time and in terms of the actors and institutions involved. The TIS approach, and the broader innovation literature from which it stems [16], rejects this model and, instead, stresses the importance of a continued interaction between numerous activities, with research, development and market formation all running in parallel and mutually reinforcing each other.

For example, firms looking to exploit the benefits of fuel cell technologies will need to cooperate with other firms and research institutes in order to develop a product. In addition,

\footnotetext{
${ }^{1}$ The history of the Dutch HyFIS goes back to the early 1950s but the analysis in this study is limited to the period from 1980 to 2007. This is because of practical limitations of time and availability of data. Moreover, it was considered sensible to focus on the most 'recent' history, as results will then be more applicable to practitioners active today.

${ }^{2}$ Also the whole point of a hydrogen-based energy system has been called into question. We do not take a stance on this matter as it is not the purpose of the analysis to evaluate the desirability of a TIS.
}

they require support from governments, e.g. subsidies or other stimuli. Governments, in turn, require a legitimate reason for spending public money. For this, it helps, for instance, that the technology has already proven itself in a controlled environment. If such feedback mechanisms are neglected, whether by policy makers or entrepreneurs, this is likely to result in the development of undesirable technologies or the absence of technological innovation altogether [17-19].

In general, the development and diffusion of an emerging technology is determined by actors, institutions and technologies $[6-9,20,21]$. These elements are interrelated and as such form the structure of the system. In order to explain technology development, a TIS analysis may focus entirely on the structures as present at a certain moment in time. However, as stated earlier, for an emerging technology a TIS has to be built up. This build-up process may only be analysed properly by (also) taking into account what actually happens to the structure of the TIS. Therefore it makes sense to also study the key activities, here called system functions, that unfold within a TIS. The analysis of structures, on one hand, and system functions, on the other, should be regarded as a combination of two approaches that reveal different aspects of reality. Both approaches will be discussed below:

\subsection{TIS structures}

Structures consist of three elements: actors, institutions and technologies. Considered from a systems perspective, these elements, and their mutual relations, are relatively stable over time. They are expected to change, but the rate of change is slow and typically only (clearly) visible from a historical point of view (more than a year).

- Actors involve organisations contributing to the emerging technology as a developer or adopter, or indirectly as a regulator, financer, etc. In this study a distinction is made between so-called enactors and selectors [14,22]. Enactors are directly involved in the development of a particular technology and fundamentally dependent on its success. They are involved from the start and actively develop and foster positive expectations around a new technology. Selectors are actors that are usually engaged into the innovation process at a later stage, drawn into the system through the positive expectations raised by enactors. Often their interest in the new technology is not fixed since they support multiple technologies. When, eventually, developments are disappointing the selectors withdraw much easier from the system than enactors do. ${ }^{3}$

\footnotetext{
${ }^{3}$ The decision to consider actors as part of the system's structure may strike some readers as an inappropriate 'structuralist' perspective. After all, actors should be considered as important agents of change; their choices and actions matter and are a key source of innovative behaviour. Still, according to the innovation systems literature, they are also part of a system made up by other actors, institutions and technologies, that shapes their behaviour in important ways. It is the mutual relation between actors, institutions and technology that is central to this study. Note that this view cannot be considered a classical structuralist perspective wherein actors are entirely determined, one-way, by institutions and/or technology.
} 
- Institutions, not to be confused with firms or organisations, are 'the rules of the game' [23], such as laws, regulations and technology standards. They also involve cognitive rules, such as problem-solving routines and dominant visions and expectations $[24,25]$.

- Technologies consist of artefacts and the material infrastructures in which they are integrated. They also involve the techno-economic workings of artefacts, including costs, safety and reliability [6].

Structural elements are merely the building blocks of the TIS. In an actual TIS, they are linked to each other, forming a holistic whole. In light of this, an important question is where the boundaries of the TIS are situated. For this study, the choice was made to consider, in detail, only Dutch actors, institutions and technologies that were specifically involved in the development, diffusion, support and use of hydrogen and fuel cell technologies, including production, distribution and use.

\subsection{System functions and cumulative causation}

This study aims to provide insight into the build-up of a TIS. The functional approach proposes that it is seven system functions that jointly determine the chances of successful TIS build-up, and, thereby eventually, the development of the underlying technological field. System functions are considered classes of activities that contribute to the development, diffusion, and use of technological innovations [26]. The list of seven system functions has been established on the basis of a review of many years of innovation systems literature [8]. Each system function is elaborately explained in Table 1.

Note that each system function may be fulfilled in various ways. For example, Knowledge Development may be supported by scientific studies or by lab experiments. It is also possible to consider activities that contribute negatively as the fulfilment of a system function. These imply a (partial) breakdown of the TIS. For example, Guidance of the Search may be undermined by continuous negative expectations about the technology involved.

For emerging sustainable energy technologies to takeoff, it is crucial that system functions reinforce each other over time, thereby resulting in a virtuous cycle. For example, the successful realisation of a research project, contributing to Knowledge Development, may result in high expectations, contributing to Guidance of the Search, among policy makers, which may, subsequently, trigger the start-up of a subsidy programme, contributing to Resource Mobilisation, which induces even more research activities; Knowledge Development, Guidance of the Search, etc. Fig. 1 provides a graphical representation of the feedback loop involved. System functions may also reinforce each other 'downwards'. In that case a sequence may result in conflicting developments or a vicious cycle.

Positive feedback loops point to the existence of a process of cumulative causation. Various empirical studies (applying a similar approach) have recently revealed that there exist different forms of cumulative causation, each one characterised by another pattern of interacting system functions [7,11-14]. These forms have been labelled motors of innovation.

Table 1 - Functions of technological innovation systems.

\begin{tabular}{|c|c|c|}
\hline System Function & Description & Event types associated \\
\hline F1. Entrepreneurial Activities & $\begin{array}{l}\text { The role of the entrepreneur is to translate knowledge } \\
\text { into business opportunities, and eventually innovations. } \\
\text { The entrepreneur does this by performing market-oriented } \\
\text { experiments that establish change, both to the emerging } \\
\text { technology and to the institutions that surround it. }\end{array}$ & $\begin{array}{l}\text { Projects with a commercial aim, } \\
\text { demonstrations }\end{array}$ \\
\hline F2. Knowledge Development & $\begin{array}{l}\text { This function involves learning activities, mostly on the } \\
\text { emerging technology, but also on markets, networks, } \\
\text { users etc. Learning activities relate to both learning- } \\
\text { by-searching and learning-by-doing. The former } \\
\text { concerns R\&D activities, whereas the latter involves } \\
\text { learning in a practical context. }\end{array}$ & Studies, laboratory trials, pilots \\
\hline F3. Knowledge Diffusion & $\begin{array}{l}\text { Innovations occur most where actors of different } \\
\text { backgrounds interact and result in interactive } \\
\text { learning. A special form of interactive } \\
\text { learning is learning-by-using, which involves } \\
\text { learning based on the experience of users. }\end{array}$ & Conferences, workshops, alliances \\
\hline F4. Guidance of the Search & $\begin{array}{l}\text { This function refers to the activities that shape the needs, } \\
\text { requirements and expectations of actors with respect to } \\
\text { their (further) support of the emerging technology. }\end{array}$ & $\begin{array}{l}\text { Expectations, promises, policy } \\
\text { targets, standards, research } \\
\text { outcomes }\end{array}$ \\
\hline F5. Market Formation & $\begin{array}{l}\text { Emerging technologies cannot be expected to compete } \\
\text { with incumbent technologies. To support innovation, } \\
\text { it is usually necessary to create artificial markets. }\end{array}$ & Market regulations, tax exemptions \\
\hline F6. Resource Mobilisation & $\begin{array}{l}\text { This function refers to the allocation of financial, } \\
\text { material and human capital. The access to such } \\
\text { capital factors is necessary for all TIS developments. }\end{array}$ & Subsidies, investments \\
\hline $\begin{array}{l}\text { F7. Support from Advocacy } \\
\text { Coalitions }\end{array}$ & $\begin{array}{l}\text { The rise of an emerging technology often leads to } \\
\text { resistance from actors with interests in the incumbent } \\
\text { energy system. In order for a TIS to develop, other actors } \\
\text { must counteract this inertia. }\end{array}$ & Lobbies, advice \\
\hline
\end{tabular}




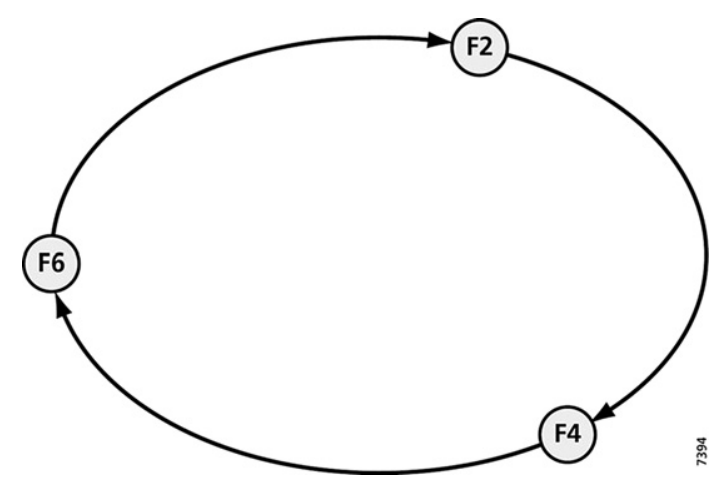

Fig. 1 - A positive feedback loop of system functions.

For example, the biofuels innovation system in the Netherlands was characterised by an Entrepreneurial Motor, driven by Entrepreneurial Activities, Support from Advocacy Coalitions and Resource Mobilisation. In another period, the system was characterised by a Science and Technology Push Motor, with weak Entrepreneurial Activities but strong Knowledge Development and Knowledge Diffusion.

This study follows up on this research by attempting to find out what motors of innovation have been present in the HyFIS and by showing under what structural conditions these motors were shaped. In this light it should be noted that the motors are not independent of the TIS structures. On the contrary, system functions, and therefore motors, develop as the result of activities undertaken by actors that operate within a pre-existing structure of institutions, technologies and other actors.

Motors are primarily related to TIS internal structures but they are, obviously, coupled to structures external to the TIS as well. After all, the workings of Dutch HyFIS actors, institutions and technologies are partly shaped by what happens abroad. Also, other technological fields are likely to influence their workings. Such external influences will be covered in the analysis.

\subsection{Method}

For the identification of structures and system functions, the event history analysis, as developed by Van de Ven and colleagues [27-29], was applied. ${ }^{4}$ The event history analysis provides a conceptual and practical basis for the systematic collection and analysis of (mostly) qualitative historical data. The following steps were taken:

- Data collection: The data for this study was gathered from historical reports (covering especially the period

\footnotetext{
${ }^{4}$ An elaborate account on event history analysis is provided by Suurs [6].

${ }^{5}$ For the analysis of the early years (1980-1995) we made use of Schaeffer [30] and Van der Hoeven [31]. These studies contain detailed information on the history of the Dutch HyFIS although without actually applying the innovation system concept.

${ }^{6}$ Initially, twelve interviews were conducted with various experts of the Dutch HyF field, including policy makers and entrepreneurs. After the analysis was done, a smaller number of additional interviews was conducted, during which the first results were checked for errors.
}

1980-1995), ${ }^{5}$ newspapers and professional journals (covering especially the most recent time period 1995-2007) and expert interviews (covering the whole period). ${ }^{6}$

- Database construction: A database was constructed containing events in chronological order. This was done by reading through literature and separating, throughout each text, the events reported. The identification of events was an inductive exercise for which the conceptual framework of system functions was used as a mental guide.

- Mapping events to system functions: The database provided a systematic overview of the content of events and the time of their occurrence. Based on this overview, the events were clustered into types that corresponded to the system functions. In Table 1, an overview is provided of types of events that correspond to each system function.

- Finding motors of innovation: The advantage of using events as indicators of system functions is that they can be connected through 'leads-to' relations, to form a sequence. For example, a promise to support the construction of a prototype may be followed by the construction of that prototype. Also, a positive lobby may result in the allocation of subsidies or the adjustment of institutions. The interaction between system functions, pointing to motors of innovation, was measured by tracking such sequences of events, like in the example of a virtuous cycle given above. The event sequences were interpreted as part of a narrative. This narrative provided the backbone for all further analysis.

- The method allowed for the identification of structures, internal and external to the TIS, that relate to the motors as underlying causes of change (drivers and barriers). For example, for each event in the narrative it is possible to find out what actors, institutions and technologies were involved.

- Triangulation: The construction of the narrative was done as 'objectively' as possible based on various sources. Still, the interpretation of the researcher is a crucial factor. To minimise personal bias, the narrative, including the motors, was verified and reconstructed by including feedback from interviews with experts.

\section{Technology outline}

A fuel cell is a device that produces power from an electrochemical reaction. It is a battery albeit one that works with a continuous supply of fuel. In most designs hydrogen is used as a fuel but it is also possible to use methanol or natural gas. ${ }^{7}$ A single fuel cell provides a small amount of power. To meet a realistic demand, multiple fuel cells need to be combined in

\footnotetext{
${ }^{7}$ During the reaction energy is released, partly in the form of electricity and partly in the form of heat. In terms of materials, the reaction consumes hydrogen and oxygen and releases water. Some fuel cells are designed to convert fossil fuels such as methanol or natural gas; these work similar but they produce $\mathrm{CO}_{2}$ as well. A fuel cell consists of two electrodes (an anode and a cathode) separated by an electrolyte. The electrolyte is a carrier of charged particles; it serves as a medium for the products of the electro-chemical reaction. The electrodes carry the electric current released by the reaction. The reaction itself is made possible by a catalyst material which adheres to the electrodes.
} 
a stack, which is a connected series of fuel cells. Such a fuel cell stack, in turn, needs to be integrated into a so-called fuel cell unit, consisting of multiple stacks, circuitry, compressors, sensors, etc. [31].

There are five types of fuel cells, named after the electrolyte used; AFC, PAFC, PEMFC, MCFC and SOFC. The characteristics of these designs differ with respect to the materials used for the various components. Different fuel cell types are based on different knowledge bases and connected to different applications; see Table 2. A key variable related to both factors is the operating temperature. High-temperature fuel cells are mostly used in Combined Heat and Power (CHP) applications whereas low-temperature fuel cells are mostly used in Fuel Cell Vehicles (FCV).

During the history of fuel cell development, a typology has been used that characterises the different fuel cell types, according to a development perspective, in terms of technology generations. ${ }^{8}$ Initially, first-generation (1G) fuel cells, the AFC and the PAFC, were distinguished from a secondgeneration (2G) fuel cell, the MCFC [30]. The 1G fuel cells were considered near-commercial but less promising than the MCFC. When the SOFC and PEMFC were developed, later in time, they were labelled third-generation (3G) technologies. The influence of these technological features will be discussed as part of the historical analysis in Section 4.

On a system level the fuel cell technology makes out a small part - the conversion part - of a chain of interrelated technologies. Other parts of the chain are production, distribution, storage and use; see Fig. 2. The organisation of this technology chain has become more complex in recent years when $3 \mathrm{G}$ technologies became dominant.

\section{The event history of the HyFIS}

This section is structured as a chronological narrative consisting of four episodes. For each episode, the shifts in the external environment of the HyFIS are sketched in the first paragraph. Then a narrative is presented in terms of events contributing to the system functions. At the end of each episode, a reflection is given, focusing on the motors that occurred and the structural drivers and barriers that enabled it.

\subsection{Rebirth (1980-1991)}

The HyFIS emerges in the 1950s and 1960s when Dutch researchers contribute to the development of the AFC and the MCFC. The work consists of research and development that fits within NASA's space programme in the USA. The 1970s, however, were characterised by a global decline of fuel cell activities due to disappointing research outcomes. The exception was the USA, where developments were sustained through NASA's Space Shuttle programme and through government support for fuel cell CHP systems [30,31,33]. In the

\footnotetext{
${ }^{8}$ Schaeffer [30] reflects in detail on the establishment and consequences of this division, pointing out how a prevailing logic of technology generations promotes promising but less mature technologies at the cost of holding back those closest to the market.
}

Table 2 - Five fuel cell types. Source: FCW [74].

\begin{tabular}{cccc}
\hline Fuel cell type & $\begin{array}{c}\text { Temperature } \\
\text { range }\left({ }^{\circ} \mathrm{C}\right)\end{array}$ & $\begin{array}{c}\text { Typical } \\
\text { application } \\
\text { domain }\end{array}$ & $\begin{array}{c}\text { Technology } \\
\text { generation }\end{array}$ \\
\hline $\begin{array}{c}\text { AFC Alkaline } \\
\text { Fuel Cell }\end{array}$ & $25-250$ & FCV & $1 \mathrm{G}$ \\
$\begin{array}{c}\text { PAFC Phosphoric } \\
\text { Acid Fuel Cell }\end{array}$ & $150-200$ & CHP & 2G \\
$\begin{array}{c}\text { MCFC Molten } \\
\text { Carbonate }\end{array}$ & $600-1000$ & CHP & 2G \\
$\begin{array}{l}\text { Fuel Cell } \\
\text { SOFC Solid } \\
\text { Oxide Fuel Cell }\end{array}$ & $600-1000$ & CHP & $3 G$ \\
$\begin{array}{c}\text { PEMFC Proton } \\
\text { Exchange }\end{array}$ & $60-100$ & FCV & $3 G$ \\
$\begin{array}{l}\text { Membrane } \\
\text { Fuel Cell }\end{array}$ & & & \\
\hline
\end{tabular}

1980s three external factors lead to a rebirth of fuel cell developments in Europe. First of all, with the second oil crisis fresh in mind, alternative energy sources receive political priority. Secondly, the environmental movement manages to put air pollution and climate change firmly on the political agenda. The third factor consists of a positive series of developments in the USA with energy companies announcing the commercialisation of CHP applications [30].

In the Netherlands, the political pressure for clean energy technologies leads to a renewed interest in fuel cells [30,31,34]. This is because fuel cells are characterised as efficient, clean and compatible with the Dutch gas-centred energy system. ${ }^{9}$ Articles begin to appear in professional journals boasting about foreign successes in the field of fuel cell research $[30,31,33] .{ }^{10}$ Urged by researchers and technology developers, the Ministry of Economic Affairs (MinEZ) ${ }^{11}$ makes plans to support fuel cell research. The fuel cell is at this time mainly considered as a means to make the conversion of natural gas into electricity as clean and efficient as possible; the use of hydrogen as an energy carrier is of marginal importance $[34,35] .{ }^{12}$

To determine the economic potential of the fuel cell, MinEZ issues feasibility studies. The results are not too positive. But scientists, inspired by developments in the USA, keep drawing positive attention to fuel cells. By the end of 1983, MinEZ consults representatives from industry and academia, with delegates from DSM (chemical engineering), Gasunie (chemical engineering), Stork (assembly), the Technical University Delft (TUd). The organisations PEO and NEOM are involved as intermediaries. ${ }^{13}$ The outcome is a proposal for a government

\footnotetext{
${ }^{9}$ The use of natural gas for production of heat and power has rapidly expanded ever since a gas field was discovered in the province of Groningen in 1959.

10 The general impression among researchers and policy makers is that the Netherlands, and Europe in general, lag behind.

${ }^{11}$ Dutch: Ministerie van Economische Zaken (MinEZ).

12 The idea is to use natural gas as an energy carrier and to apply reformer technology for the production of hydrogen 'on-site'.

${ }^{13}$ PEO is the office for Energy Research Projects (Dutch: Projectbureau Energieonderzoeksprojecten). NEOM is the Dutch Energy Research Company (Dutch: Nederlandse Energieontwikkelingsmaatschappij). Later PEO is merged with NEOM to form Novem/SenterNovem.
} 


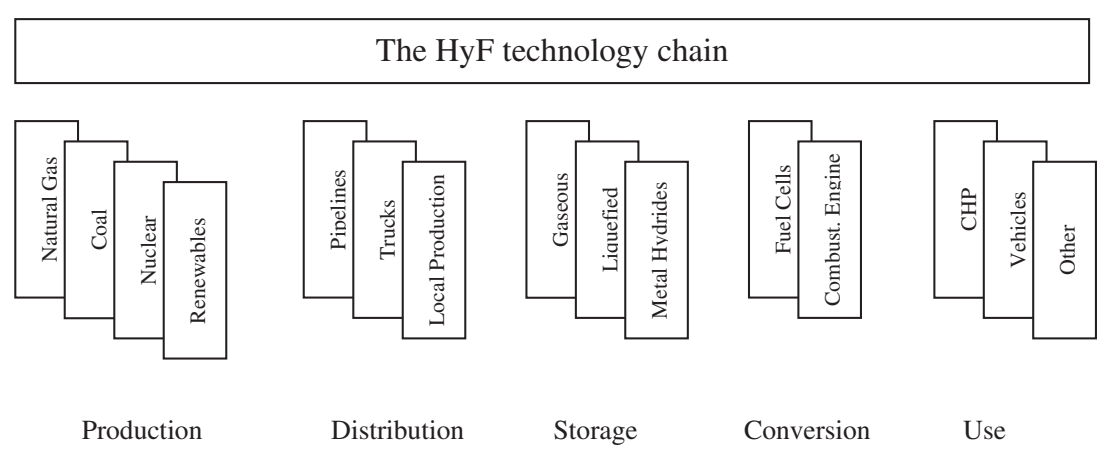

Fig. 2 - The HyF technology chain; source: Bakker et al. [32].

support programme, the National Fuel Cell Research programme (NOB), ${ }^{14}$ large enough to induce industry building $[30,31]$.

The NOB will be directed by ECN, an energy research institute $[30,31]$. It is decided that of the technologies available - AFC, PAFC and MCFC - the MCFC, a 2G fuel cell technology, is the best candidate for government support. The NOB dedicates a small share of the programme to support the PAFC as well. ${ }^{15}$ Since the PAFC project is far less prominent than the MCFC, its development will not be discussed further.

For the MCFC demonstration, a first step is to bring in foreign knowledge. An agreement is arranged with IGT, an American engineering company [31]. ${ }^{16}$ The second step is to find project partners. On the supply-side there are actors from academia (TUd) and from the assembly industry (Stork, De Schelde). The commitment of launching customers, however, is limited. A number of large firms shows interest but, in the end, they decline because the payback time is considered too long. Another, more general, issue is that the MCFC seems to offer limited economic opportunities [30,31]. Natural gas prices are low and an important alternative technology, the gas turbine, is rapidly gaining ground in terms of costs and environmental performance [35].

The promise of these firms participating nevertheless leads to high expectations among MinEZ and ECN. The optimism is again supported by developments in the USA, where IGT has announced commercialisation plans for the MCFC [31]. As a result budgets are upgraded $[30,31] .{ }^{17}$ The critical issue, however, remains to find launching customers. From 1988 to 1992 various energy companies are approached to consider participation but without success.

It is through dedicated support by ECN and MinEZ that the NOB is continued anyway. Eventually they manage to draw in

\footnotetext{
${ }^{14}$ Dutch: Nationaal Onderzoeksprogramma Brandstofcellen.

${ }^{15}$ The AFC is at this time being developed by Elenco, a joint venture of DSM and the Belgian Study Centre for Nuclear Energy and Bekaert [30]. Elenco is supported by Novem through the EUREKA programme in a project which aims to construct an AFC fuel cell bus [31,36-38].

${ }^{16}$ IGT has been developing the technology that TNO, a Dutch research institute, has abandoned in 1969.

${ }^{17}$ Budgets (for five years) are increased to Fl 60 million (Fl 45 million of which is government money) of which Fl 40 million is allocated to the MCFC project [30].
}

two energy companies interested in acquiring knowledge on clean energy technologies. By this time, in 1992, ECN establishes a joint venture with Stork and De Schelde, known as the Dutch Fuel Cell Corporation (BCN). ${ }^{18}$

\subsubsection{Motors}

The most developed system functions in this period are Knowledge Development, Knowledge Diffusion, Guidance of the Search and Resource Mobilisation. The build-up of the TIS is mostly driven by scientists and policy makers contributing to Knowledge Diffusion and Guidance of the Search. Based on developments in the USA, they manage to influence policy makers, thereby leading to contributions to Guidance of the Search and Resource Mobilisation as embodied in the NOB programme. Within the framework of the NOB, technology developers and policy makers embark on joint efforts to commercialise MCFC technology, as reflected in contributions to Knowledge Development, Knowledge Diffusion, Guidance of the Search and, to a lesser extent, Entrepreneurial Activities. Depending on the outcome of Knowledge Development, this affects Guidance of the Search, thereby leading to shifts in Resource Mobilisation, in the form of budgetary adjustments, and, again, Guidance of the Search, in the form of adjustments to the programme.

Given the central position of Knowledge Development, Knowledge Diffusion, Guidance of the Search and Resource Mobilisation, it seems fit to label this dynamic a Science and Technology Push (STP) Motor. The most important feature of the STP Motor is the establishment of a knowledge base in 2G fuel cell technologies. Moreover, HyF technology, and the related industry building ambitions, have become a spearhead of Dutch energy policy.

\subsubsection{Structural drivers and barriers}

The main driver of the STP Motor is a group of enactors: the researchers and technology developers that initiate the setting up of the NOB. This group fuels its dynamics with positive expectations. The enactors manage to convince policy makers on the national level (the most important selectors during this period) to support the HyFIS and offset negative research outcomes with future promises based on experiences in the USA. They were successful even to such an

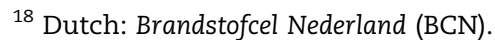


Table 3 - HyFIS drivers and barriers and impacts underlying an STP Motor in the period 1980-1991.

\begin{tabular}{|c|c|c|c|}
\hline & Actors & Institutions & Technologies \\
\hline Drivers & $\begin{array}{l}\text { - Scientists and technology } \\
\text { developers occupy the enactor role. } \\
\text { - The national government is the } \\
\text { main selector. } \\
\text { - The enactor group manages to } \\
\text { persuade the national government } \\
\text { to support HyF technologies. } \\
\text { The strategy of the enactors is to } \\
\text { make powerful promises by referring } \\
\text { to a combination of environmental } \\
\text { issues, economic issues and technological } \\
\text { breakthroughs abroad. }\end{array}$ & $\begin{array}{l}\text { - Oil crisis (external). } \\
\text { - Environmental pressure } \\
\text { (external). } \\
\text { - Government ambitions of } \\
\text { industry building (external). } \\
\text { - The perspective of lagging } \\
\text { behind internationally. } \\
\text { - The NOB programme. }\end{array}$ & $\begin{array}{l}\text { - The fuel cell's possible role } \\
\text { in clean efficient CHP systems } \\
\text { (external). } \\
\text { - Technological breakthroughs } \\
\text { in the USA (external). }\end{array}$ \\
\hline Barriers & $\begin{array}{l}\text { - The group of enactors and selectors is } \\
\text { very small. } \\
\text { - Limited involvement of launching } \\
\text { customers. }\end{array}$ & $\begin{array}{l}\text { - Government rules for public } \\
\text { financing hamper international } \\
\text { cooperation (external). } \\
\text { - The positive expectations of the fuel } \\
\text { cell are not widely shared among } \\
\text { industries (external). }\end{array}$ & $\begin{array}{l}\text { - Competition from the gas } \\
\text { turbine (external). } \\
\text { - The fuel cell is technologically } \\
\text { immature and costly. }\end{array}$ \\
\hline
\end{tabular}

extent that policy makers became like enactors themselves. The NOB programme itself is an important institutional driver. It gives a strong and lasting impulse to Guidance of the Search and Resource Mobilisation.

A main barrier is formed by feasibility studies recurrently pointing out that the market perspective for the MCFC is poor. The effect is that potential selectors from industry, especially launching customers, are unwilling to participate in the NOB, resulting in a poor contribution to Entrepreneurial Activities. A related barrier is the sudden emergence of the gas turbine as a low-cost competitor in the market for clean and efficient CHP systems.

An overview of structural drivers and barriers is presented in Table 3.

\subsection{The end of a technology push? (1992-1998)}

The 1990s are characterised by general government cutbacks which lead to the downsizing of funds available. A second factor is an international shift in HyF technology development. For $1 \mathrm{G}$ as well as $2 \mathrm{G}$ fuel cells it turns out that despite long-term market support programmes (in Japan and the USA), production costs remain high compared with other technologies on the CHP market [30]. At the same time, 3G fuel cells are undergoing rapid improvements and cost reductions.

The joint venture BCN commences with the MCFC demonstration in 1992. The project, labelled BCN-1, turns out to be technologically feasible and a prototype stack of $2 \mathrm{~kW}$ is constructed in the same year $[39,40]$. But scaling up to commercial size at reasonable costs is problematic $[40,41]$. The consequence is that BCN-1 stops halfway.

The MCFC project is continued anyway but the strategy is now to buy the required stacks. Moreover, BCN increases international cooperation and attracts European funding [30]. In 1996 a second project, $\mathrm{BCN}-2$, is started with the aim to construct a $40 \mathrm{~kW}$ CHP system to be applied in hospitals. A search for partners leads to the participation of British Gas, Gaz de France and Sydkraft [31]. Unfortunately, feasibility studies show, again, that such a system will be uncompetitive, even if mass produced. In 1998, BCN stops the project $[33,40]$.

The declining support for the MCFC and 2G HyF technologies in general, is in line with international trends [31]. Anticipating on this development, ECN has gradually been shifting research efforts to the next generation of technologies that is now emerging, the SOFC and the PEMFC. Fortunately, the SOFC fits well with the MCFC knowledge base developed, because both fuel cell technologies are based on ceramic components [34,40]. The research is carried out in cooperation with firms and research institutes $[30,40,42] .{ }^{19}$ The research is co-financed through the EU Joule programme [31,42]. In 1994-1995, the project yields important outcomes as two customers, Sulzer (Swiss) and Siemens (Germany), are willing to commercialise SOFCs for their CHP systems [30].

Interest in SOFC technology does not just originate from ECN but also from energy firms not involved in the NOB. In 1993 the energy companies that were earlier involved in BCN1 develop plans for an SOFC field test as well [31]. The project is co-financed by Novem, the government's energy agency. The unit (eventually) works well and is kept in operation for three years [43]. ${ }^{20}$

By the end of 1998 the NOB is subjected to an evaluation. Despite the commercial success of the SOFC trajectory, most projects have encountered severe problems, especially in the light of industry building ambitions [33]. This urges MinEZ to stop the programme $[31,33]$. The NOB is considered a success with respect to $\mathrm{R} \& \mathrm{D}$ but a failure where industry building and emission reduction are concerned [31,33].

\footnotetext{
19 The participants are TNO, Technical University Delft (TUd), Technical University Twente (TUt) and, later, Siemens.

${ }^{20}$ The technology is bought from Westinghouse (from Pittsburgh, USA) [31].
} 
Table 4 - HyFIS drivers, barriers and impacts underlying an STP Motor in the period 1992-1998.

\begin{tabular}{|c|c|c|c|}
\hline & Actors & Institutions & Technologies \\
\hline Drivers & $\begin{array}{l}\text { - Technical universities, ECN and other } \\
\text { technology developers still occupy } \\
\text { the enactor role. } \\
\text { - The most important selectors are } \\
\text { governments and (a small number of) } \\
\text { launching customers. } \\
\text { - Enactors and selectors are well connected } \\
\text { in a network. } \\
\text { - Selectors are increasingly from abroad, e.g., } \\
\text { the EU government and foreign energy } \\
\text { companies. } \\
\text { - The strategy taken by enactors and selectors is } \\
\text { to persuade launching customers to participate } \\
\text { in subsidised demonstration projects. } \\
\text { - Another strategy is to diversify support } \\
\text { by allocating resources to a broad variety } \\
\text { of technologies including } 3 G \text { technologies. }\end{array}$ & $\begin{array}{l}\text { - Persistent high expectations of HyF } \\
\text { technologies among enactors. } \\
\text { - The NOB programme is broadened } \\
\text { to include a variety of technologies } \\
\text { ( } 2 \mathrm{G} \text { and } 3 G \text { ). } \\
\text { - The development of a broad R\&D } \\
\text { portfolio within the NOB. }\end{array}$ & $\begin{array}{l}\text { - Rise of 3G fuel cell } \\
\text { technologies (external). }\end{array}$ \\
\hline Barriers & - Launching customers are still barely involved. & $\begin{array}{l}\text { - General government cutbacks in } \\
\text { energy research (external) } \\
\text { - Demonstrations recurrently } \\
\text { point out that cost reductions } \\
\text { are difficult to realise. }\end{array}$ & $\begin{array}{l}\text { - Decline of } 1 \mathrm{G} \text { and } 2 \mathrm{G} \text { fuel } \\
\text { cell technologies (external). } \\
\text { - Competition from the gas } \\
\text { turbine (external). } \\
\text { - The fuel cell is still technologically } \\
\text { immature and costly. } \\
\text { - Progress is made in the } \\
\text { development of } 2 \mathrm{G} \text { technologies } \\
\text { but results are disappointing. }\end{array}$ \\
\hline
\end{tabular}

\subsubsection{Motors}

The dominant system functions during this episode are still Knowledge Development, Knowledge Diffusion, Guidance of the Search, Resource Mobilisation and, now becoming more important, Entrepreneurial Activities. In terms of interaction, the STP Motor identified in the previous period remains active. After all, it is still Guidance of the Search and Resource Mobilisation, fulfilled through the NOB programme, that provides continuity to developments within the HyFIS. A notable change, however, is the abandonment of projects related to $1 \mathrm{G}$ and $2 \mathrm{G}$ fuel cells after a series of negative outcomes urges technology developers to recognise the poor market perspective for these technologies. This is a change in comparison to the previous period when technology developers managed to push policy support by neglecting negative research outcomes and by referring to new international successes. A main outcome of the STP Motor is the development of a knowledge base, not so much based on feasibility studies and market explorations but increasingly on pilots and practical demonstrations. Unfortunately, most of these demonstrations show that commercialisation attempts are bound to fail.

\subsubsection{Structural drivers and barriers}

The HyFIS is still heavily affected by external developments in the international HyF field, mostly concerning the rise of $3 \mathrm{G}$ technologies. Internal to the HyFIS, the key driver is the NOB, which - with ECN and various technology developers as dominant enactors - continues to feed the STP Motor. A positive development set in motion by the same enactors is to rapidly pick up on this technological shift. The promise of $3 G$ fuel cells triggers a renewed interest among various selectors to participate in the setting up of demonstration projects. The demonstration projects result in important contributions to Guidance of the Search.

Despite some launching customers playing a crucial role in this period as technology selectors, demand for HyF technology remains practically absent. This is due to the fact that research outcomes consequently point out that fuel cells cannot be expected to compete with alternative technologies on the CHP market. This results in the termination of the NOB, and, with it, the core of the STP Motor. Despite the termination of the programme, there remains a strong supply-side and knowledge infrastructure with powerful enactors at its basis.

An overview of structural drivers and barriers is presented in Table 4.

\subsection{Reorganisation (1999-2003)}

In the new millennium, environmental issues become more urgent in political arenas and the fuel cell is increasingly considered as the basis of a sustainable energy system, now especially including the mobility domain. ${ }^{21} \mathrm{~A}$ key event is the Californian ZEV policy that started in the early 1990s and is now beginning to affect fuel cell developments. ${ }^{22}$ As a result of

\footnotetext{
${ }^{21}$ Until 1995 fuel cell research was focused on power production but now mobility becomes the main driver.

${ }^{22}$ California's ZEV (Zero-Emission Vehicles) policy was issued in 1990. It consists of a directive to make $10 \%$ of the Californian car market completely emission free by 2003.
} 
this policy, Daimler buys the Canadian company Ballard Power Systems, the world's number one PEMFC producer, and starts developing fuel cell vehicles. This creates an incentive for large car manufacturers to enter the field as well. The money involved in fuel cell research increases internationally $[30,33]$.

High expectations for the PEMFC and the SOFC have built up among Dutch scientists and policy makers [43-47]. The NOB has been terminated but based on the positive outlook for $3 \mathrm{G}$ fuel cell technologies, ECN manages to convince MinEZ and Novem to reallocate financial resources to various generic subsidy programmes. ${ }^{23}$ This way, ECN continues to diversify away from the MCFC $[31,34,35,43]$. The SOFC trajectory is particularly successful as ECN manages to start a spin-off company (InDEC) that specialises in the supply of SOFC stacks $[34]{ }^{24}$ For the PEMFC, the necessary adaptations are more fundamental but a PEMFC research track is nevertheless rapidly initiated. ${ }^{25}$

ECN's research activities are largely included in generic energy research programmes such as EOS. These subsidy programmes are also open to proposals from other firms. Thereby a framework is created that facilitates other organisations to start $\mathrm{HyF}$ research projects. ${ }^{26}$ An important implication is that support is now no longer exclusively directed by MinEZ but also by other government ministries, most notably the Ministry of the Environment (MinVrom). ${ }^{27}$ More importantly, the support is no longer directed, via ECN, towards particular technologies. Instead, various projects are proposed and legitimated by firms themselves [40,48-50].

The policy framework combined with the promising outlook of PEMFC technology results in the involvement of numerous firms. For instance, DSM introduces a foil called Solupor to improve Ballard's stack design [31]. ${ }^{28}$ In cooperation with ECN and Novem, DSM manages to set up a plant for the production of the Solupor which is eventually adopted by Ballard [31,51]. A second example is AKZO Nobel, a chemical company involved in the development of membrane separation techniques.

The focus within the HyFIS has so far been on the fuel cell as a centralised energy conversion device for the natural-gas based energy supply system. A reorientation is set in motion by the promise of PEMFC technology and its (decentralised) applications in the mobility domain. As a result, more attention is given, often by firms previously not part of the HyFIS, to other parts of the HyF technology chain, including production,

\footnotetext{
${ }^{23}$ Most notably the EOS energy research subsidy programme.

${ }^{24}$ The downside to this story is that the original plan was to involve incumbent industries but the ceramics sector is not interested due to the limited size of the market [34].

${ }^{25}$ In fact, ECN had already started a small basic research track on the PEMFC, in cooperation with TNO, in the 1990s [31,43].

${ }^{26}$ Such project proposals are subjected to tender procedures, meaning that projects - including non-HyF related projects - have to compete with each other in terms of criteria of innovativeness and sustainability.

${ }^{27}$ Dutch: Ministerie van Volkshuisvesting, Ruimtelijke Ordening en Milieubeheer (MinVROM).

${ }^{28}$ This foil is useful as a matrix to hold the electrolyte of the fuel cell.
}

distribution and storage of hydrogen $[35,49,52]$. An important example is Shell, an oil company, venturing into fuel processing technology and in the development of PEMFC refuelling infrastructure $[35,50,53] .{ }^{29}$ This fuel processing technology is supposed to enable the decentralised conversion of hydrocarbons into hydrogen. ${ }^{30}$

The increasing importance of HyF technology in the mobility domain is underlined by the CUTE project [55]. CUTE is directed by DaimlerChrysler and Ballard and supported by the EU [37]. The project, which already started in 1998, involves the demonstration of PEMFC buses in nine European cities with the purpose of developing and testing various well-to-wheel chains, including the production and distribution of hydrogen. In Amsterdam the key actor is GVB, the city's public transport company, which regards hydrogen as a welcome opportunity to develop a clean transport system [37]. ${ }^{31}$

The initiative for these projects comes primarily from firms depending on subsidies. To acquire these, they rely on their lobbying power, which is directed to local and national governments but also the EU. ${ }^{32}$

\subsubsection{Motors}

At the outset of this episode the STP Motor is still present, as Knowledge Development, Guidance of the Search and Resource Mobilisation activities continue to shape the HyFIS. However, the pattern of events is gradually changing as firms start taking the initiative to develop Entrepreneurial Activities. Driven by a renewed Guidance of the Search, related to 3G technologies, technology developers lobby the government for financial support, thereby inducing Support from Advocacy Coalitions and Resource Mobilisation. If successful in acquiring funding, the firms embark on Knowledge Development, in the form of studies and prototype development, and Entrepreneurial Activities, in the form of technology demonstrations. The outcomes affect Guidance of the Search, thereby feeding back on Entrepreneurial Activities again, in the form of new firms entering the TIS.

The Entrepreneurial Activities have a pivotal position in this virtuous cycle. Therefore this motor will be called an Entrepreneurial Motor. It differs from the STP Motor where the Entrepreneurial Activities are an important outcome but not so much a driver of further developments.

Note that this period is characterised by a phase-out of the STP Motor and the (gradual) build-up of the Entrepreneurial Motor. Government policies are no longer based on support for specific technologies but on generic funding. Partly as a result of this, the HyFIS develops into a larger system, more varied in terms of firms (supply-side enactors) as well as government

\footnotetext{
${ }^{29}$ Shell Hydrogen, a business unit within Shell, specialises in the development of refuelling infrastructure and in reformer technology for mobility applications [54]. Other examples are Gastec, the Dutch division of Plug Power, and Hexion (later Hygear).

${ }^{30}$ Reformer systems convert natural gas, or another hydrocarbon, into hydrogen.

${ }^{31}$ Other partners are Hoek Loos (pressured storage), Shell (infrastructure) and Nuon (supplier of green electricity).

${ }^{32}$ For example, GVB acquires $30 \%$ of the necessary finances from the EU and, with the aid of Novem, it manages to persuade MinVROM, the municipality of Amsterdam and various firms to provide funding as well [56-59].
} 
Table 5 - HyFIS drivers, barriers and impacts underlying an Entrepreneurial Motor in the period 1999-2003.

\begin{tabular}{|c|c|c|c|}
\hline & Actors & Institutions & Technologies \\
\hline Drivers & $\begin{array}{l}\text { - The enactor group consists of a variety } \\
\text { of actors, particularly research institutes } \\
\text { and technology developers. } \\
\text { - Important selectors are governments and } \\
\text { an increasing number of companies, } \\
\text { especially car manufacturers and fuel } \\
\text { cell developers. } \\
\text { - The enactors support a variety of fuel cells } \\
\text { and fuel cell-related infrastructure } \\
\text { technologies. } \\
\text { - The enactors make renewed promises, } \\
\text { based on the 3G technologies and large } \\
\text { investments made by car companies abroad. }\end{array}$ & $\begin{array}{l}\text { - Sustainable mobility becomes an } \\
\text { important policy issue (external) } \\
\text { - The vision of a sustainable hydrogen } \\
\text { energy system becomes dominant } \\
\text { (external). } \\
\text { - The broad research portfolio of ECN } \\
\text { facilitates a quick reorientation } \\
\text { towards } 3 G \text { technologies. } \\
\text { - Subsidy programmes like EOS provide } \\
\text { generic funding for new HyF projects. }\end{array}$ & $\begin{array}{l}\text { - The 3G technologies, especially } \\
\text { the PEMFC, become the dominant } \\
\text { technologies (external). } \\
\text { - Mobility becomes the dominant } \\
\text { application domain (external). } \\
\text { - The } 3 G \text { technologies happen } \\
\text { to match with the knowledge } \\
\text { base already built up around } \\
\text { 2G technologies. }\end{array}$ \\
\hline Barriers & $\begin{array}{l}\text { - Launching customers are still lacking. } \\
\text { - Dependence on foreign development. } \\
\text { - Lack of networks. }\end{array}$ & $\begin{array}{l}\text { The TIS is becoming more complex due } \\
\text { to the increasing number of actors, } \\
\text { technologies and institutions involved. } \\
\text { There is a lack of institutions that } \\
\text { provide coordination. }\end{array}$ & $\begin{array}{l}\text { - Further decline of } 1 \mathrm{G} \text { and } 2 \mathrm{G} \\
\text { fuel cell technologies (external). } \\
\text { - The fuel cell (also } 3 \mathrm{G} \text { ) is still } \\
\text { technologically immature } \\
\text { and costly. } \\
\text { - The focus on decentralised } \\
\text { applications of fuel cells means } \\
\text { that the limitations of infrastructure } \\
\text { become more pressing. }\end{array}$ \\
\hline
\end{tabular}

structures. Another striking development is the technological and industrial reorientation towards $3 \mathrm{G} \mathrm{HyF}$ technologies and, related to this, a broad hydrogen infrastructure.

\subsubsection{Structural drivers and barriers}

An important external driver of this period is the rise of the PEMFC as a promising new technology. The promise is especially powerful since it is backed up by car manufacturers (abroad) making large investments. The enactors within the HyFIS see commercial opportunities for developing PEMFC technology. They make use of this development by fuelling expectations, thereby contributing to Guidance of the Search, among selector groups, most importantly the national government. A key institutional driver is formed by government policies that result in a variety of companies entering the HyFIS, thereby boosting Entrepreneurial Activities. The reorientation towards $3 \mathrm{G}$ technologies is also driven by the strategy of ECN, which manages to diversify away from the MCFC to the SOFC and the PEMFC technologies.

A severe barrier of the Entrepreneurial Motor is still the absence of a strong a demand for the fuel cell. Launching customers are still lacking. Another barrier is the increased complexity of the HyFIS as, from a technological, institutional and actor perspective, the HyFIS structure is rapidly expanding. With more firms involved across the HyF technology chain, promoting various technologies and tapping into support schemes directed by different government ministries, coordination becomes more difficult.

An overview of structural drivers and barriers is presented in Table 5.

\subsection{A proto-market (2004-2007)}

The EU massively increases its support for HyF technology [54]. Climate change is the main driver, though security of supply is becoming important as well as oil prices are rapidly increasing. The EU's main strategy is to establish a publicprivate partnership network, leading to a joint undertaking (Joint Technology Initiative) to direct large demonstration projects. ${ }^{33}$ Another driver is the increasing regulatory pressure with respect to air quality. EU emission norms have been implemented in Dutch law in 2001 [61] and they are exceeded in many areas [62] thereby providing local governments with strong incentives to support alternative fuels.

Demonstrations are abundant in this period and lead to a greater visibility of HyF technology $[35,48]$. A key example is GVB's work as part of the CUTE project. By 2004, two PEMFC buses are in service in Amsterdam and the first Dutch hydrogen refuelling station is built [37]. Also, Nedstack, a spin-off from AKZO Nobel, builds the first PEMFC power plant in Delfzijl. ${ }^{34}$ On the international level, Shell is involved in the construction of the world's first hydrogen refuelling stations in Reykjavik, Washington and Tokyo [63]. The projects are executed in cooperation with GM, which supplies a fleet of FCVs.

Local governments support the demonstration trend as well. This started already with the municipality of Amsterdam financing GVB's activities within CUTE [37], but now also Arnhem and Rotterdam make plans for supporting PEMFC applications [64]. Local governments are particularly driven by the urgency of the air pollution problem but also by the opportunity of local economic development $[37,50] .{ }^{35}$

Generally, these projects are partly funded by the firms and partly through government subsidies connected to the generic subsidy programmes mentioned above $[36,65]$.

\footnotetext{
${ }^{33}$ The EU plans to contribute 500 million $€$ over six years, to be matched by the industries involved [60].

${ }^{34}$ The $50 \mathrm{~kW}$ PEMFC power plant is constructed by a consortium of which also Nedstack and AKZO Nobel are part.

${ }^{35}$ In Arnhem as well as in Amsterdam, the initiators are local entrepreneurs pressing for government support. For example: GVB, Nedstack, Hexion, Gastec, Nuon.
} 
The HyFIS is expanding as all kinds of actors and firms are entering. This expansion is also visible in research communities, as underlined by the launch of the $\mathrm{SH}_{2}$ programme. ${ }^{36}$ The $\mathrm{SH}_{2}$ is a research programme set up as a public-private partnership. The focus is on catalytic processes and especially on hydrogen production and storage $[35,66]$. Notable partners are the energy production companies Shell (fuels), Nuon (power) and Gasunie (gas).

With the expansion of the HyFIS, there is an increasing need for coordination. SenterNovem (previously Novem) and ECN are therefore becoming more important as mediators. Also, formal networks are established through which knowledge is exchanged. A key event is the formation of the Dutch Hydrogen Association (NWV) by SenterNovem and a variety of firms. The NWV plays an important role in knowledge exchange $[36,40,67]$. The $\mathrm{SH}_{2}$ mentioned above also contributes to the exchange of knowledge in the field, especially within the research community $[35,40]$.

Larger fuel cell applications are manufactured by multinationals, especially car manufacturers. In the Netherlands such system integrators are lacking. This poses a problem as the choices that such companies make with regard to their applications are crucial in determining the value of particular HyF technologies. Dependency on foreign system integrators is illustrated by Shell's exploration of reformer technology. In 2001 the oil company established a joint venture with UTC Fuel Cells, named Hydrogensource. When, a few years later, car manufacturers massively turned to on-board hydrogen storage options, the prospects for on-board reforming turned bleak and Hydrogensource was dissolved $[40,68]$. As a result, Shell stops pursuing on-board reforming, and turns to the development of infrastructure in cooperation with car manufacturers abroad. Its strategy is to strengthen its role as a lobbyist by taking a role in important platforms mostly on the EU level $[35,53,65,69]{ }^{37}$

So far the generic government support schemes have been sufficient, even to expand the level of activities built up in the past $[70,71] .{ }^{38}$ Nevertheless firms and policy makers now increasingly call for technology specific policies that could serve to coordinate and bundle the large variety of activities and eventually stimulate market development [59,70,72]. This awareness is associated with the emergence of a so-called transition approach among policy makers. In a way, transition policies imply a return to the industry building strategy developed in the 1980 s $[49,67,73]$. The idea is to equip publicprivate partnerships, so-called transition platforms, with the task to develop strategies for the support of specific technological trajectories. For HyF technology this is done by the

\footnotetext{
${ }^{36}$ ACTS Sustainable Hydrogen set up by the Dutch Research Council (NWO).

${ }^{37}$ ECN also experiences troubles with commercialising their PEMFC technology [34]. To solve this, ECN decides to develop a fuel cell vehicle itself. The result, in 2007, is the HydroGEM, a PEMFC vehicle developed partly with technology from DaimlerChrysler. The HydroGEM is the first Dutch-made hydrogen powered vehicle.

${ }^{38}$ Indeed public funding is high compared with other European countries. The annual budget for hydrogen and fuel cell projects has exceeded 30 million $€$; about 10 million $€$ is of public origin $[43,70,71]$.
}

Platform New Gas (PNG) [72,74] which, in 2006, advises the national government to provide direction to the HyFIS by focusing support on three regional clusters: Rotterdam, Arnhem and the northern provinces [74].

The government follows the recommendations of the PNG and thereby makes a step in the direction of a technology specific policy approach based on the vision that HyF technologies are to play a role in a future energy system. At the time of writing, by 2008, it is not clear to what extent this approach will be successful. In any case it seems reasonable that the HyFIS will continue to develop progressively since the rise in fuel cell activities is part of an international trend of growing positive expectations. This development is accompanied by large cost reductions of PEMFC fuel cells and the first commercial fuel cell applications $[40,50,53,65] .{ }^{39}$ As production gradually increases, further cost reductions may be expected, bringing the PEMFC ever closer to the commercial energy market.

\subsubsection{Motors}

The dominant system functions in this period are still Entrepreneurial Activities, Knowledge Development, Knowledge Diffusion, Guidance of the Search, Resource Mobilisation and Support from Advocacy Coalitions, with the latter becoming more important. A system function that starts to develop is Market Formation. In terms of interaction, the progression of events follows the logic of the Entrepreneurial Motor, but its dynamic has become stronger. The Entrepreneurial Activities are increasingly fulfilled by large firms formerly not involved in the HyFIS. Also, Knowledge Diffusion is strengthened by actors forming networks and the nature of Resource Mobilisation changes as support comes increasingly from large firms and EU programmes. Most importantly, the HyFIS changes with respect to Guidance of the Search as a number of demonstration projects results in PEMFC applications which are visible to the public. In short, the system functions that make up the Entrepreneurial Motor are strengthened through parallel improvements to various parts of the HyFIS.

The Entrepreneurial Motor has resulted in the entry of a variety of actors, mostly enactors supplying fuel cells, infrastructure and system components. In this respect, the dynamic continues along similar lines as in the previous period. There are, however, two important developments that have not been observed before. The first is related to the rise of successful PEMFC applications in the form of visible demonstration projects. This gives a renewed boost to a belief in HyF technology among potential technology selectors. Indeed, with ongoing cost reductions of PEMFC technologies, the promise of a market gains credibility. A second impact is that networks are established from which political activities are developed.

\subsubsection{Structural drivers and barriers}

Important external drivers in this period are the HyF specific policies of the EU on one hand, and the air quality regulations as maintained by local governments on the other. On top of this, there is important progress in bringing down the costs of PEMFC technology. These factors provide incentives for local governments and firms to enter the HyFIS and effectively

\footnotetext{
${ }^{39}$ Most notably back-up systems for ICT services and forklifts.
} 
becoming enactors of HyF technology. The air quality regulation induces Market Formation, as it sets conditions that strongly favour zero-emission vehicles. The enactors manage to strengthen the HyFIS in important ways, constituting two more drivers. Firstly, the enactors start to connect more to each other and also to selectors, the most important ones being the national government, the EU and foreign car manufacturers outside the HyFIS, thereby contributing strongly to Knowledge Diffusion and also to Support from Advocacy Coalitions. The second driver is the setting up, in a joint effort by enactors and selectors, of PEMFC demonstrations visible to the public. Obviously, these provide important contributions to Entrepreneurial Activities, Knowledge Development and Knowledge Diffusion. Through their visibility, they especially contribute to Guidance of the Search, thereby making the entry of new enactors and selectors more likely.

The international dimension is a driver of the HyFIS but it is also a threat in the sense that the HyFIS becomes increasingly dependent on foreign industries. This is true for the demand-side, which increasingly depends on car manufacturers and other system integrators, but also for the government structure which becomes increasingly reliant on policies originally designed by the EU government. This relates to another barrier, the absence of coordination. The larger part of HyF activities in this episode is initiated by firms, enactors and selectors, each with its own vision and goal. This variety has so far stimulated HyF developments but enactors and selectors increasingly urge the national government to coordinate and bundle the great variety of activities. National policies provide Guidance of the Search in the form of support for research trajectories pursued by ECN. But with the increasing number and variety of enactors and selectors entering the HyFIS, the government should also provide Guidance of the Search for the more market-oriented projects.

An overview of structural drivers and barriers is presented in Table 6.

\section{Conclusion}

The aim of this article was to analyse the development of the Dutch HyFIS, with as a general goal, to provide insights into the dynamics that shaped this development. In order to fulfil this aim, we attempted (i) to identify motors of innovation and (ii) to point out underlying structural drivers and barriers. This section summarises the most important results, provides lessons for practitioners and ends with a short discussion of the theoretical approach.

\subsection{Summary}

At the outset of this article it was mentioned that the HyFIS has developed for a long period of time, and yet market formation has remained insignificant. The analysis has pointed out that this development can be ascribed to the continuous unfolding of two consecutive motors of innovation, a Science and Technology Push Motor and an Entrepreneurial Motor.

Table 6 - HyFIS drivers, barriers and impacts underlying an Entrepreneurial Motor in the period 2004-2008.

\section{Actors}

Drivers - Research institutes and an increasing number of technology developers are still the most important enactors. Local governments are also taking on the enactor role as the urgency of the air quality issue increases.

- The main selectors are a large number of governments (local, national, EU) and some utilities.

- The strategy taken by enactors and selectors is to form networks. These involve knowledge networks but also more policy-industry related networks.

- Another strategy is to develop visible demonstrations and involve the general public.

- Numerous networks are established. Especially the more politically oriented organisations aim for the development of a system wide infrastructure and technology specific policies.

Barriers • Launching customer and system integrators are lacking.

- Increasing dependence on selectors abroad.

- Lack of networks.

Institutions

Technologies

- EU level policies and public-private - The 3G technologies, especially partnerships (external).

- Local air quality regulations (external).

- Local economic development issues (external)

- Generic subsidy programmes provide funding.

- Rise of public-private partnerships. - The technologies become

- The level of coordination increases.

- There is the promise of a market for $3 \mathrm{G}$ technologies.

- There is still a lack of institutions that provide coordination.

- There is a lack of systemic policies. the PEMFC, become the dominant technologies (external)

- Mobility becomes the dominant application domain (external)

- The costs of $3 \mathrm{G}$ technologies are going down rapidly (mostly external). visible to the public due to abundant technology demonstrations in the public sphere.

- The costs of 3G technologies are rapidly decreasing. A multitude of applications show that the technology is reliable.

- The fuel cell (also $3 \mathrm{G}$ ) is still technologically immature and costly (external).

- The focus on decentralised applications of fuel cells means that the limitations of infrastructure become more pressing. 
The first motor, the Science and Technology Push (STP) Motor involved expectations and research outcomes, communicated mostly by scientists and technology developers, contributing to Guidance of the Search. Eventually this led to the setting up of a government-supported R\&D programme, which reinforced Guidance of the Search and, directly linked to it, Resource Mobilisation, in the form of R\&D subsidies. This resulted in Knowledge Development, in the form of basic research, feasibility studies and pilots with, depending on the outcomes, a reinforcement of Guidance of the Search. This led to the expansion of the R\&D programme, thereby closing a virtuous cycle. Eventually, developments also led to a number of firms participating in government initiated Entrepreneurial Activities. An important feature of this motor was the build-up of a strong knowledge base and the development of institutions, both formal and informal, in support of HyF technologies.

The second motor observed was the Entrepreneurial Motor. At the core of this motor's dynamics were Entrepreneurial Activities. Driven by Guidance of the Search, technology developers and demand-side firms lobbied the government for financial support, thereby contributing to Support from Advocacy Coalitions and Resource Mobilisation. If successful in acquiring funding, the firms embarked on Knowledge Development, in the form of studies and prototype development, and Entrepreneurial Activities in the form of technology demonstrations. The outcomes affected Guidance of the Search, and thereby fed back into Entrepreneurial Activities, in the form of new businesses entering the TIS. An important feature of these developments was an increasing variety of enactors and selectors. This corresponded with a steady development of networks. The technological variety of the system also increased: various HyF technologies were developed in parallel and were increasingly integrated into applications.

Both motors were driven by enactors which continued to feed positive expectations to a group of selectors, in spite of evidence suggesting that commercialisation was still far away. These enactors managed to frame the disappointing outcomes of $R \& D$ as positively as possible, either by referring to (new) future visions or by opportunistically referring to shifting external developments.

All the time, enactors managed to expand their networks gradually, building up more developed institutions and more reliable technologies. Through building up structures, the STP Motor was followed up by a more powerful Entrepreneurial Motor. This way the Dutch HyFIS gradually developed into a more complete TIS over time. It started out with a rather supply-sided structural configuration, able to contribute to no more than a narrow sub-set of system functions concentrating around knowledge development. Eventually, the enactors (and supportive selectors) managed to realise a TIS, consisting of a variety of structures, which was contributing to a broad range of system functions.

Despite the fact that motors primarily involve internal TIS dynamics, it should be stressed that dynamics were strongly coupled to external influences. For example, the STP Motor was driven by scientists and technology developers 'importing' technological knowledge from abroad or collaborating with foreign companies. Also, when the Entrepreneurial Motor emerged, policy makers and firms were increasingly preoccupied with car industries and EU level policies.

\subsection{Lessons for practitioners}

The analysis has shown that the build-up of a TIS is a troublesome process, characterised by uncertainty and adversity but also by luck and opportunity. However, the results also indicated that strategies may be developed to increase the chances of success. The following recommendations apply on a practical level:

Even though the actors in the HyFIS have managed to build-up a variety of structures, still much work needs to be done to further develop the system. A logical next step would be to get more users involved and to start building a hydrogen infrastructure. Without these two elements, the Entrepreneurial motor may come to exist for a long time without making any more progress in bringing hydrogen and fuel cell technologies closer to the market. In order to realise this, it is recommendable that developments are focused on specific regions, as is currently being done. By developing regional policies that aim for full fletched hydrogen energy systems, more practical experience will be gained. The resulting learning experiences, user involvement, build-up of expectations, adaptation to local policy regimes, are necessary before a larger diffusion of hydrogen and fuel cell technologies is, currently, even thinkable.

Actors need to be less occupied with their particular projects and more aware of regional, or even system wide, interests. By employing a coordinated action, an intensive lobby may be organised to gain funding and commitment for experimentation with hydrogen and fuel cell technologies in one or two regional settings. In terms of dynamics, this means that the HyFIS may shift into a pattern of cumulative causation that is characterised by so-called system building activities [14]. Such a HyFIS will be more coordinated and marketoriented and therefore less dependent on external shocks.

On a more general level, policy makers, and other practitioners, should prepare strategies that target the dynamics of the build-up of a TIS. This could be done by monitoring TIS dynamics, by supporting the conditions that drive motors of innovation and by overcoming the barriers that hamper them.

The linear model of innovation still forms the basic mindset of many practitioners. However, the reality is that technology will only develop successfully when multiple system functions are developed in parallel. Policy makers (and other selectors) need to:

-... create a long-term vision of a sustainable future energy system and develop clear policy directives in order to contribute to its realisation. Such visions should incorporate the requirement of multiple technologies. This degree of variety is essential to preserve flexibility in future development.

- ... develop technology assessment and policy evaluation methods, possibly based on the framework applied in this study, that take into account processes (system functions) and not (only) technological outcomes or market diffusion.

- ... develop cooperation strategies involving industries but also regional, national and European level governments, focusing on cross-border cooperation and market creation measures. 
- ... act as a launching customer (technology procurement) and regulator of (niche) markets.

Motors of innovation may only emerge if, at the same time, entrepreneurs (or other enactors) in support of a specific technology:

- ... invest in knowledge diffusion beyond projects besides knowledge development.

- ... employ a 'management of expectations' strategy in an early stage, thereby drawing attention to possible partners and future customers.

- ... organise themselves in networks, consisting of policy makers and other entrepreneurs, in which they may develop system overarching strategies, on a regional basis, for coordination and (political) support for further developments.

- ... draw in powerful industries and lobby to various levels of government to gain support for the emerging technology.

-... involve end-users in practical applications as soon as possible.

\subsection{Further research}

Recently, the TIS approach and the system functions framework is being adopted by an increasing number of scholars. Interestingly, very similar forms of cumulative causation have been identified in a previous study by Suurs \& Hekkert [14] the formation of the biofuels innovation system in the Netherlands. This clearly points to the possibility of identifying general patterns of cumulative causation, i.e. mechanisms that hold across various cases. Additional studies may confirm, refine or perhaps reject the results established so far. More case studies may be conducted on sustainable energy technologies but the TIS approach may be applied to other technological fields, beyond the energy domain, as well.

The event history analysis method provides a powerful basis for conducting case studies in such a way that they can be compared. If carried out properly, a series of case studies could result in theoretical insights in the dynamics of emerging technologies. In light of the insights developed so far, it seems particularly interesting to develop a framework in which various forms of cumulative causation, i.e. motors of innovation, are related to each other. For example, it could be the case that a weak and precarious motor, like the STP motor, generally precedes a more advanced motor, like the Entrepreneurial motor. The possibility of motors following up on each other would open up important opportunities for intervention strategies.

This all basically means continuing the line of research proposed in this article. However, there are also some weaknesses of the framework that need to be addressed:

- The enactor/selector distinction offers a crude conceptualisation of actor roles. It does help understand why certain actors prefer particular strategies. However, the TIS approach could benefit from a more sophisticated actor concept. One possible step worth taking could be the inclusion of intermediaries: actors that are somewhere in between the worlds of enactors and selectors. ${ }^{40}$

- The technology specific orientation of the TIS analysis brings the risk of evaluating a development as an advocate of a technology. It would be interesting, especially from a policy perspective, to develop a broader perspective and thereby analysing a variety of TISs, including multiple motors of innovation unfolding in parallel.

- So far, recommendations have been provided on a strategic level rather than instrumental. An important improvement would be to develop a set of tools and instruments that would help practitioners active on an operational level to get involved in innovation system building.

\section{Acknowledgements}

We would like to thank all those people who provided valuable input in the research conducted for this paper. We are also grateful to Staffan Jacobsson for detailed comments on different versions of this paper. The Dutch organisation for scientific research (NWO) and the Knowledge Network on System Innovations (KSI) are thanked for financial support.

\section{R E F E R E N C E S}

[1] Barreto L, Makihira A, Riahi K. The hydrogen economy in the 21st century: a sustainable development scenario. International Journal of Hydrogen Energy 2003;28:267-84.

[2] Clark WW, Rifkin J. A green hydrogen economy. Energy Policy 2006;34:2630-9.

[3] Sanborn Scott D. Fossil Sources: "Running Out" is not the problem. International Journal of Hydrogen Energy 2005;30:1-7.

[4] Winter C-J. Into the hydrogen energy economy-milestones. International Journal of Hydrogen Energy 2005;30:681-5.

[5] Carlsson B, Jacobsson S, Holmén M, Rickne A. Innovation systems: analytical and methodological issues. Research Policy 2002;31:233-45.

[6] Suurs RAA. Motors of sustainable innovation. Towards a theory on the dynamics of technological innovation systems, thesis, Utrecht University, Utrecht; 2009.

[7] Suurs RAA, Hekkert MP. Cumulative causation in the formation of a technological innovation system: the case of biofuels in the Netherlands. Technological Forecasting \& Social Change 2009;76:1003-20.

[8] Hekkert MP, Suurs RAA, Negro SO, Kuhlmann S, Smits REHM. Functions of innovation systems: a new approach for analysing technological change. Technological Forecasting \& Social Change 2007;74:413-32.

[9] Jacobsson S, Bergek A. Transforming the energy sector: the evolution of technological systems in renewable energy technology. Industrial and Corporate Change 2004;13:815.

[10] Myrdal G. Economic theory and underdeveloped regions. London: Methuen \& Co LTD; 1957.

[11] Hillman KM, Suurs RAA, Hekkert MP, Sandén BA. Cumulative causation in biofuels development: a critical comparison of the Netherlands and Sweden. TASM 2008;20:593-612.

[12] Negro SO, Suurs RAA, Hekkert MP. The bumpy road of biomass gasification in the Netherlands: explaining the rise

\footnotetext{
${ }^{40}$ This idea is in fact already part of the enactors/selectors framework by Garud \& Ahlstrom. We did not incorporate it in this study for the sake simplicity.
} 
and fall of an emerging innovation system. Technological Forecasting and Social Change 2008;75:57-77.

[13] Suurs RAA, Hekkert MP. Competition between first and second generation technologies: lessons from the formation of a biofuels innovation system in the Netherlands. Energy 2009;34:669-79.

[14] Suurs RAA, Hekkert MP, Smits REHM. Understanding the formative stage of technological innovation system development. The case of natural gas as an automotive fuel. Energy Policy, in press.

[15] Godin B. The linear model of innovation: the historical construction of an analytical framework. Science Technology \& Human Values 2006;31:639-67.

[16] Kline SJ, Rosenberg NR. An overview of innovation. In: Landau R, Rosenberg N, editors. The positive sum strategy harnessing technology for economic growth an overview of innovation. Washington DC: National Academic Press; 1986.

[17] Klein Woolthuis R, Lankhuizen M, Gilsing V. A system failure framework for innovation policy design. Technovation 2005; 25:609-19.

[18] Smits REHM. Innovation studies in the 21st century. Technological Forecasting and Social Change 2002; 69:861-83.

[19] Smits REHM, Hertog PD. TA and the management of innovation in economy and society. International Journal of Foresight and Innovation Policy 2006;3:28-52.

[20] Jacobsson S, Johnson A. The diffusion of renewable energy technology: an analytical framework and key issues for research. Energy Policy 2000;28:625-40.

[21] Markard J, Truffer B. Technological innovation systems and the multi-level perspective: towards an integrated framework. Research Policy 2008;37:596-615.

[22] Garud R, Ahlstrom D. Technology assessment: a sociocognitive perspective. Journal of Engineering and Technology Management 1997;14:25-48.

[23] North DC. Institutions, institutional change and economic performance. New York: Cambridge University Press; 1990.

[24] Van Lente H. Promising technology - dynamics of expectations in technological developments, thesis, Twente University, Enschede; 1993.

[25] Van Lente H, Rip A. Expectations in technological developments: an example of prospective structures to be filled in by agency. In: Disco C, van der Meulen B, editors. Getting new technologies together expectations in technological developments: an example of prospective structures to be filled in by agency. Berlin - New York: Walter De Gruyter; 1998.

[26] Bergek A. Shaping and exploiting technological opportunities: the case of renewable energy technology in Sweden, thesis, Chalmers University of Technology, Göteborg, Sweden; 2002.

[27] Poole MS, van de Ven AH, Dooley K, Holmes ME. Organizational change and innovation processes, theories and methods for research; Oxford: Oxford University Press; 2000.

[28] Van de Ven AH. Methods for studying innovation development in the minnesota innovation research program. Organization Science 1990;1:313-35.

[29] Van de Ven AH. The innovation journey. New York: Oxford University Press; 1999.

[30] Schaeffer G.J. Fuel cells for the future. A contribution to technology forecasting from a technology dynamics perspective thesis, Twente University, Enschede; 1998.

[31] Van der Hoeven D. Een gedurfd bod. Nederland zet in op de brandstofcel. Bergen: Beta Text; 2001.

[32] Bakker S, Van Lente H, Meeus M. Arenas of expectations for hydrogen technologies. Innovation Studies Utrecht (ISU) Working Paper \#08.19 2008.
[33] ECN. Energieverslag Nederland 1998.

[34] ECN. Personal communication with a senior fuel cell research manager; 2007.

[35] SenterNovem. Personal communication with a senior policy advisor; 2007.

[36] Air Products. Personal communication with project engineer; 2007.

[37] GVB. Personal communication with the senior project manager GVB Amsterdam/ CUTE project; 2007.

[38] Kordesch K, Cifrain M. Alkaline fuel cells (an overview), 204th meeting of the electrochemical society; 2003.

[39] ECN. Energieverslag Nederland; 1993.

[40] Technical University Delft. Personal communication with a senior researcher involved in fuel cell research since the 1980s; 2007.

[41] ECN. Energieverslag Nederland; 1995.

[42] Luiten EEM, Blok K. Energy R\&D in the Netherlands (report prepared for the USA Department of Energy). Pacific Northwest National Laboratory; 1999.

[43] IEA. Hydrogen \& fuel cells. Review of national R\&D programs; 2004.

[44] FD. Waterstof kan helpen bij beter klimaatbeleid. Het Financieele Dagblad November 27th 1996.

[45] NRC. Waterstof op de Wadden; nieuwe perspectieven voor energiebron zonder co2. NRC Handelsblad December 7th 1996.

[46] AD. Gassector tegen stadsverwarming. Algemeen Dagblad October 14th 1996.

[47] DV. Naderende waterstof. De Volkskrant November 30th 1996

[48] IEA. Iea agreement on the production and utilization of hydrogen (annual report). Golden, CO USA: National Renewable Energy Laboratory; 2000.

[49] MinVROM. Personal communication with a senior policy maker; 2007.

[50] Nedstack. Personal communication with the director; 2007.

[51] ECN Ballard announces that it will use reinforced membrane technology developed by ECN/DSM. Website: http://www. ecn.nl/en/h2sf/news/ballard-uses-solupor/; 2004.

[52] RTD. Hydrogen is on the way. RTDinfo Magazine on European Research 2004;42. August 2004.

[53] Plug Power. Personal communication with a senior project manager; 2007.

[54] Solomon BD, Banerjee A. A global survey of hydrogen energy research, development and policy. Energy Policy 2006;34:781-92.

[55] Haraldsson K, Folkesson A, Saxe M, Alvfors P. A first report on the attitude towards hydrogen fuel cell buses in Stockholm. International Journal of Hydrogen Energy 2006; 31:317-25.

[56] ANP. GVB wil 11 miljoen voor schone stadsbussen. Algemeen Nederlands Persbureau April 7th 2000.

[57] ANP. Amsterdam trekt 7 miljoen uit voor waterstofbus. Algemeen Nederlands Persbureau December 20th 2000.

[58] DV. Waterstof drijft de Amsterdamse stadsbussen voort. De Volkskrant September 2nd 2000.

[59] SenterNovem/ IPE. Personal communication with a senior policy advisor; 2007.

[60] EU Commission promotes take-up of hydrogen cars and the development of hydrogen technologies. EU Press Release IP/ 07/1468; October 10th 2007.

[61] DG. Besluit luchtkwaliteit, Dutch Government. Staatsblad 2001;269:1-58.

[62] MNP. Fijn stof nader bekeken. De stand van zaken in het dossier fijn stof. Milieu- En Natuur Planbureau; 2005.

[63] ANP Shell en GM bouwen tankstation voor waterstof. Algemeen Nederlands Persbureau March 5th 2003.

[64] ANP. Arnhem werpt zich op waterstof. Algemeen Nederlands Persbureau May 19th 2005 
[65] FZ. Personal communication with one of the directors of Formula Zero (FZ); 2007.

[66] NWO. Nederlandse Organisatie voor Wetenschappelijk Onderzoek (NWO). Website:. Den Haag http://www.nwo.nl/ nwohome.nsf/pages/NWOP_5A5K8D_Eng; 2007.

[67] NWV. Personal communication with the chairman of the NWV. Nederlandse Waterstof Vereniging; 2007.

[68] HS. Website: www.hydrogensource.com; 2004. Hydrogensource press release.

[69] SenterNovem. Personal communication with a senior policy advisor; 2008.
[70] SN SenterNovem. Waterstofinnovatie in Nederland (rapport); 2003.

[71] SenterNovem. Waterstof in perspectief (powerpointslides); 2005.

[72] Van der Hoeven D. Symfonie in nieuw gas. Platform Nieuw Gas; 2005.

[73] MinEZ. Personal communication with a senior policy maker; 2007.

[74] PNG. Waterstof brandstof voor transities (vision document). Platform Nieuw Gas; 2006. 